\title{
THEORETICAL AND PRACTICAL ISSUES IN BUSINESS VALUATION
}

\author{
Florin Turcas PhD Candidate
}

Bucharest Academy of Economic Studies

E-mail: turcasflo@gmail.com

Florin Dumiter Professor PhD

„Vasile Goldis” Western University of Arad

E-mail: fdumiter@yahoo.com

Petre Brezeanu Professor PhD

Bucharest Academy of Economic Studies

E-mail: brezeanupetre@yahoo.com

Stefania Jimon Master Student

„Vasile Goldis” Western University of Arad

E-mail: jimonstefania@yahoo.com

(Received June 2016; Accepted October 2016)

This paper was funded from the European Social Found, through the Sectorial Operational Programme Human Resources Development 2007-2013, project number POSDRU/ 187/1.5/S/155656 „Support for doctoral students in economic sciences”.

\begin{abstract}
Business valuation is dealing with a series of difficulties, legislative and/or normative inaccuracies, as well as problems related to divergent results obtained by standard approaches. This material is synthesizing some of these problems, highlighting possible research directions. Each of the standard approaches is investigated, theoretically and practically analyzed, and the conclusions constitute a basis for developing new theories in the field of valuation.
\end{abstract}

Keywords: Valuation approaches, Stock market, Discounts

\section{Introduction}

Shapiro (2013) affirmed that it is expected for independent assessors to obtain different values, as long as they will operate with different assumptions.

If it is active, the market will equalize these assumptions and values, the comparison with transactions of same asset or similar assets representing the best image on the value of asset evaluated. The recent financial crisis has demonstrated, however, that market is unable to regulate itself if the perturbations exceed a certain critical level. Therefore, we question whether to trust the value of a financial asset determined exclusively by its listing on the market transactions. 


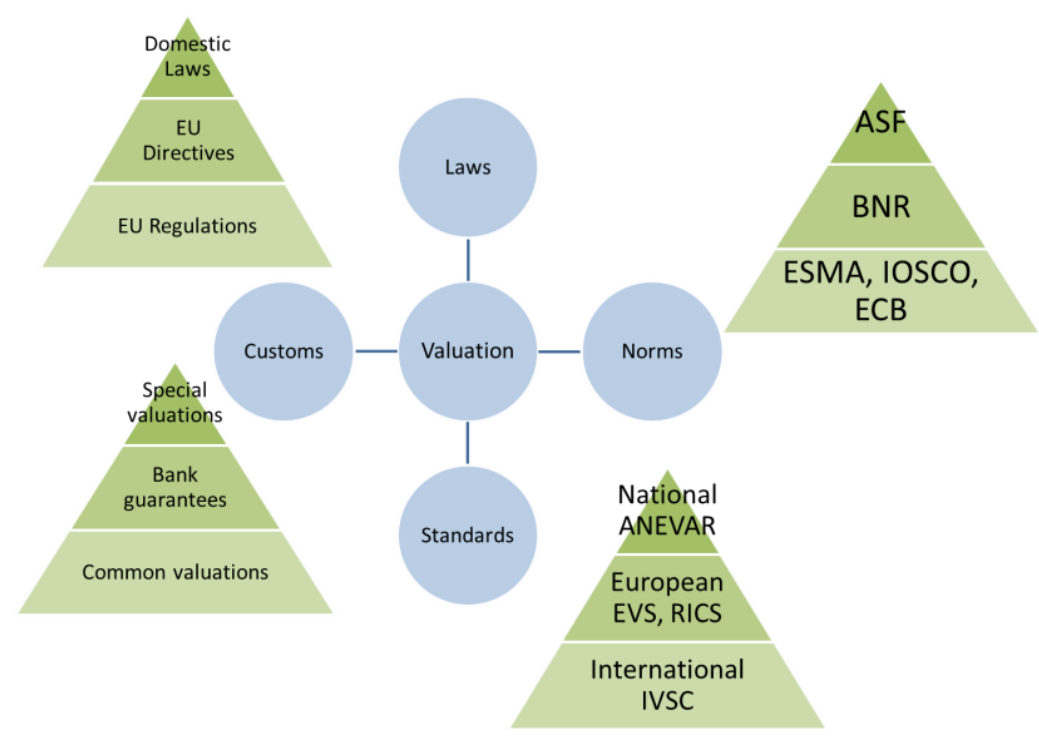

Figure 1. Legislating valuation process

Source: Diagram developed by authors

\section{Methodology}

With an experience of over 20 years in evaluations, authors have faced various situations in which legislative norms contravened with standards or customs accepted by market, different approaches have generated divergent results, or cases where market transactions were made at prices theoretically difficult to justify.

Therefore, authors decided to systematically inspect all the approaches mentioned in the current standards as well as in works of famous authors, checking their applicability on various practical cases.

There where theoretical results that did not correspond to the practical experience, authors sought logical explanations, proposing practical solutions for reconciliation.

Finally, authors prepared the field for issuing new theories about valuation of financial assets, theories which in our opinion, can equalize the three main current approaches, divergently.

\section{Enterprise value}

Evaluations standards from Romania, ANEVAR (2015), aligned to the International Valuations Standards (2013), define value as rather a grounded and 
justified opinion, than a sure fact. Based on analysis, assets value can be determined either by "the most probable" price that is expected to be traded, either by future economic benefits, which assets can generate.

According to the valuation standards, the "Enterprise value is - total value of enterprise own capitals (enterprise value for all its owners), plus its loans or interest-bearing liabilities value, minus any cash or cash equivalent available to pay those liabilities."

The logic of this definition is justified by the American economic system: to fully dispose of the cash flows of an enterprise, all its shares must be purchased (own capitals) and all its financial liabilities paid-off. Obviously, any available amount existing in enterprise (including outside exploitations assets or redundant ones which are valuated at market value) can be used to extinguish liabilities, so it must be reduced.

Applying the above mentioned definition in certain particular cases raises a series of problems, as how result from analysis of following situations is encountered in current practice.

First problems appear in the situation in which availability exceeds summed value of debts and shares. Schmidlin (2014) interprets the situation as an anomaly, but because in this situation there is a series of issuers on domestic stock market, the situation must be thorough.

For example, case of Financial Invest Companies (SIF), listed on Bucharest Stock Exchange (BVB), is the most conclusive. According to net asset value reported (VAN) at 27.11.2015, for Banat - Crisana Financial Invest Company (SIF 1) the situation is as follows:

- current assets, represented by listed shares (quasi-liquid assets), have a total value of 1,124,241,127 lei;

- the issuer does not have debts to credit institutions, or debentures;

- stock market capitalization value was 1.5960 lei/share x548,849,268 shares

$=875,963,432$ lei (closing stock exchange rate at the same date).

In these conditions, a negative enterprise value may result: 875,963,432 $1,124,241,127=-248,277,695$ lei.

This result has the following theoretical significance: an investor with considerable financial power will purchase whole SIF1 shares (expending for this purpose $875,963,432$ lei), will sell immediately liquid assets (obtaining 1,124,241,127 lei) and will record an excess of 248,277,695 lei. Immobilized titles and existing floating capital are added to this fact, so the investor would make an immediate profit from operation.

The explanation of this result comes, firstly, from the fact that the net asset evaluated after regulations issued by the Financial Supervisory Authority (ASF) is 
of 3.2589 lei/share, more than double against the stock exchange course. In our opinion, undervaluation is mainly due to the weakness of domestic capital market, lack and/or reticence of investors, as well as regulations that limited the holdings of shares issued by SIFs.

The second aspect to mention in this case is the fact that, although the stock exchange course is set by the market, it is not expected from an interested investor to be able to buy at this price all the shares, including control holdings. Firstly, because a buying pressure will lead to a price increase. Secondly, because investors who accumulate shares do not consider that the market price is relevant, so will consider that the discount for lack of control is included in the stock exchange course.

Another relevant aspect frequently found in practice is that of enterprises found in difficulties, respective valuations for insolvency. Usual, this valuation reports have an important role in taking the decision to apply a reorganization plan or not, respectively to establish categories of creditors to be paid by accomplishment of assets.

Two problems may rise in this case:

- Tax liabilities interpretations. These are not interest bearing, but involve penalties and delay increases, with same economic effect. In our opinion, tax liabilities must be regarded similar to credit institutions liabilities, although the notion of ,tax credit” is not legally accepted;

- Situation in which liabilities exceed net assets. A null value for issuer's shares results, according to International Accounting Standards IAS 32 Financial Instruments: presentation ,an own capital instrument is any contract which certificates the existence of a residual interest in a society assets after deducting all its liabilities." However, if net liabilities are positive, an enterprise value greater than those assets results, fact that leads to the conclusion that, an investor who will pay all liabilities to take over the insolvency enterprise, will own a smaller fortune than the invested amount. In practice, this problem is solved by excluding some creditor categories from creditors table in bankruptcy case, respectively partial payment of remaining ones.

\section{Approaches in valuation}

Standards indicates three principal approaches in valuation, based on intuitive fundamental economic principles. Alongside standards, others reference works in the field (Palepu, 2013; Schmidlin, 2014; Fabozzi, 2011) recommend same valuation approaches: by cost (patrimonial, based on balance), by income (profitability, returns) and by market (comparison). 
Regarding the valuation approaches applicability, standards for enterprises and/or shares provide recommendation to apply market and income approaches. The cost approach must be avoided, being available only where others do not offer credible results, respectively where liquidation value of individual assets is bigger than the value determined in conditions of continuing activity. Obviously, cost approach has no sense only if evaluated participation gives the right to liquidate assets (respectively majority participations), respectively if this liquidation is possible and probable.

ANEVAR Standards (2015) define approaches as:

- Market approaches compares the subject asset with known transactions of other similar assets, on the equilibrium price principle (between demand and supply);

- Income approaches, based on anticipating benefits principle, is determining asset value based on future benefits generated by it;

- Cost approaches (substitution principle) is based on the fact that it is expected for the investors to pay for an asset an equivalent amount with the cost required for obtaining or reconstructing an asset with similar use.

In our opinion, these approaches correspond to sellers' expectation (cost approach, because it represents the effort integrated over time in that enterprise), buyers (income approach, because represent an image of the utility of participation acquisition), respectively demand-supply equilibrium (market comparison approach).

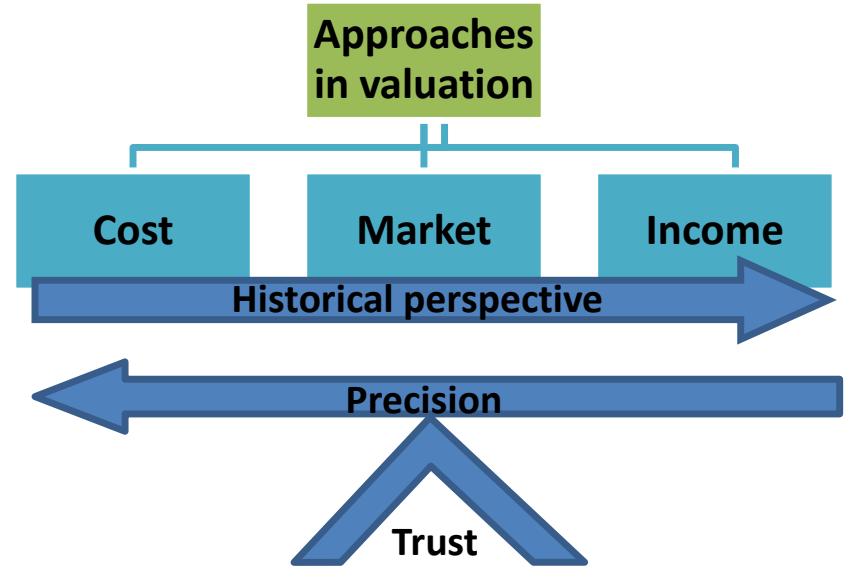

Figure 2. Main valuation approaches

Source: Diagram developed by authors

DE GRUYTER OPEN
Studia Universitatis "Vasile Goldis" Arad. Economics Series Vol 26 Issue 4/2016 ISSN: 1584-2339; (online) ISSN: 2285 - 3065

Web: publicatii.uvvg.ro/index.php/studiaeconomia.Pages $1-23$ 


\section{Legislative considerations}

Evaluations present a particular importance, especially where the price set by the assessor determines the obligation of the parties to respect it: to accounting registration, litigation cases, to set the damages, etc. Therefore, a complex valuation must satisfy a whole number of norms, laws and standards, not all convergent.

Many independent institutions being involved in valuations regulations', do not surprise the appearance of situations in which norms are divergent, sometimes contradictory. Evaluation practice highlights irreconcilable situations, in which normative papers lead to contradictory results in valuation:

- Valuation standards consequently promote selecting values based on date relevance, market customs and assessor professional experience. They exclude average between different approaches, recommending value reconciliation using expert judgment;

- Companies Law no. 31/1190 imposes that the proposed price must be the average of at least two values, if valuation is made in order to compensate shareholders in case they want to retire as a result of fusion, division or major changes in company activity;

- Exchange market Law no. 297/2004 stipulates that the imposed price in some conditions for mandatory takeover offer to be the maximum of the medium trading price in the last 12 months, the highest price paid by a bidder in last year, unitary value of the net asset and value proposed by an independent assessor.

In this sense, in case of a corporatist restructuring operation (fusion or division) it is possible to be necessary to prepare three separate evaluation reports, each governed by distinct legislative norms and which can lead to unequal results.

Beyond these legislatives aspects, which hold more of valuation practice than the academical substrate of the problem, a series of practical situations question even the theoretical bases of approaches frequently used in valuations.

\section{Cost approach}

This method is mostly used for assets that do not have a market, which are rare or not at all traded, for unlisted securities, respectively in case of major participations or of those that may decide assets liquidation.

Most mutual funds from Romania calculate unlisted shares value, or untraded in the last month, after enterprise net value asset, as it result from our own study, resumed in Table 1. 
are presented in Table 2. For the same period, same auditor provides different substantial results, due to application of International Financial Reporting Standards.

Table 2. Own capitals and result of SIF1

\begin{tabular}{|l|c|c|c|c|}
\hline \multicolumn{1}{|c|}{ Indicator } & \multicolumn{2}{|c|}{ According IVth Directive } & \multicolumn{2}{c|}{ According IFRS } \\
\hline \multicolumn{1}{|c|}{ [lei] } & $\mathbf{2 0 1 1}$ & $\mathbf{2 0 1 2}$ & $\mathbf{2 0 1 1}$ & $\mathbf{2 0 1 2}$ \\
\hline Own capitals & 642.598 .332 & 874.623 .718 & 1.282 .102 .701 & 1.193 .894 .525 \\
\hline Net result & 63.006 .519 & 100.514 .044 & 140.091 .788 & -197.202 .902 \\
\hline
\end{tabular}

Source: Issuer reports, www.sif1.ro

Implications for assessors, but especially for investors, are important:

- Financial reports constitute the base the valuating based on cost leaves from. The result is that simply different interpretations of some accounting registrations can lead to alteration of enterprise valuation results;

- Net accounting asset value is at the base for calculating the PBV indicator (Price per Book Value), one of the most important of the usual, taken into consideration by investors. Changing the value of indicator depending only on accounting regulations (and not of economic activity in fact of the issuer) proves the fragility of indicator.

Passing over accounting and taxing considerations, as well as over the investor's uncertainty, the possible different treatment of same assets raises problems to assessors, including theoretical ones. Therefore, the interpretation of some balance sheet items from the perspective of assessor is not always simple and unequivocal. From the examples encountered in practice we mention:

- Accounting accruals situation. In many cases these contain incomes/expenditures already made, which follows just to be sequentially settled in time. In our opinion this should be considered as being effective in the valuation moment, following to affect directly the results account;

- Grants situation. Accounting norms allow their settlement on amortization extend, in a determined period. From the assessor's point of view, we opine that grand's balance must be integrally added to the active balance sheet, being in fact a collected value in enterprise;

- Postpone profit tax. For example, in case of assets sells before year of 2009, when, according with fiscal norms, the registration of difference between price and accounting value in reserve account without tax payment was possible, at removal of recording of immobilization. According to actual fiscal norms, changing of reserve destination, including its distribution to 
shareholders, involves tax payment, fact which is why we opine that assessor must take care of this tax at passive correction;

- Contingent assets and liabilities. These are coming from contracts with possible future judicial effects, but which does not accomplish conditions to be accounted at valuation date. We opine that task of detecting these agreements, as well as evaluating the effect on issuer, is the duty of expert assessors who execute the due diligence.

- Situation of enterprises that have to report financial situations both IFRS and GAAP (American standards). The penalties situation imposed on AG White Pharmaceuticals Company is known (described in detail by Palepu, 2014), thanks to recording expenses with research and transoceanic collaboration: a correct approach according to GAAP standards, but not according to IFRS standards. Otherwise, an entire series of works highlight similarities, but especially discrepancies between standards.

\section{Market approach}

It is possible anywhere, where there is a relevant and active market this is the most desirable valuation approach. It is, otherwise, the quintessence of value, because the market is offering immediate change value of an asset.

\section{Theoretical considerations}

Naturally, minority shares packages must be evaluated at market value, determined by exchange rate displayed by main stock exchange on which the issuer is listed. In this direction, are conforming both legislatives disposal (Valuation Standard ANEVAR GME 600 Enterprise valuation, CNVM Regulation no.9/2014, 13 International Financial Reporting Standard. Valuation at fair value, 2004/25/CE European Parliament and Council Directive, IOSCO Final Report on Principles for the Valuation of Collective Investment Schemes), and majority bibliographical studied sources (Sapiro, 2013; Choudhry, 2010; PricewaterhouseCoopers, 2014).

Market approach compares subject asset with similar enterprises, participations, shares or assets, which were traded on market and with any relevant transactions (or offers) of same enterprise shares (or its components). For relevance, the comparable items must have similar quantitative and qualitative characteristics with subject, dates must be verifiable, and transactions must have been impartial. Valuation is based on using multiplies (value rates) determined for comparable items, selected by intern consistence criteria and applied to subject enterprise: 
Turcas F., Dumiter F., Brezeanu P., Jimon S. (2016)

Theoretical and practical issues in business valuation

$$
\mathrm{M}=\frac{\mathrm{V}_{\mathrm{c}}}{\mathrm{E}_{\mathrm{c}}} ; \quad \mathrm{Vi}=\mathrm{M} \cdot \mathrm{E}
$$

where $\mathrm{M}=$ multiplier, $\mathrm{Vi}$ = enterprise capital (capital market value), $\mathrm{E}=$ relevant economic parameter; additional index c refers to comparable items.

Most frequently used rates are those related to economic efficiency (profit - PER, EBIT, EBITDA), assets value (P/BV) or dividends (DY):

$$
\mathrm{PER}=\frac{\mathrm{Pps}}{\mathrm{EPS}} \quad \mathrm{P} / \mathrm{BV}=\frac{\mathrm{MC}}{\mathrm{TE}} \quad \mathrm{DY}=\frac{\mathrm{Dps}}{\mathrm{Pps}}
$$

In which: PER $=$ Price Earnings Ratio, Pps $=$ share price (stock exchange course), EPS = earnings per share, $\mathrm{P} / \mathrm{BV}=$ Price per Book Value, $\mathrm{MC}=$ market capitalization, $\mathrm{TE}=$ net accounting assets, DY $=$ Dividend Yield, Dps = dividend per share.

\section{Identified problems}

Of course, the most important problem is that markets are found in a state of unstable equilibrium, present big variations, what makes the proposed value to be very volatile. Here it is not only about sub-minute speculations, high risk markets (FOREX), or unstable markets/titles (sometimes manipulated). Germany assessors had proposed even a „long term value for a real estate”, a kind of intrinsic value, and immune to the moment variations of the market.

Indicators published on stock exchange were analyzed (80 issuer, on BVB main market) and presented as:

Tabel 3. Stock exchange indicators of listed enterprises at BVB

\begin{tabular}{|c|c|c|c|c|}
\hline Symbol & ALR & ALT & VESY & VNC \\
\hline ISIN & ROALROACN & ROALTCACN & ROVESYACN & ROVRUACN \\
\hline Capitalization & 827.270 .017 & 32.480 .901 & 5.287 .365 & 76.352 .664 \\
\hline Own capitals & 1.194 .974 .592 & 73.148 .048 & 18.354 .080 & 108.525 .920 \\
\hline Own capital date & 31.12 .2013 & 31.12 .2013 & 31.12 .2013 & 31.12 .2013 \\
\hline PBV & 0,69 & 0,44 & 0,29 & 0,7 \\
\hline PER & $-6,86$ & 38,56 & $-4,89$ & $-11,19$ \\
\hline DIVY & 27,31 & & 6,3 & 31.12 .2013 \\
\hline PER date & 31.12 .2013 & 31.12 .2013 & 31.12 .2013 & 2008 \\
\hline Year Dividend & 2011 & 2008 & 2008 & \\
\hline
\end{tabular}


Turcas F., Dumiter F., Brezeanu P., Jimon S. (2016)

Theoretical and practical issues in business valuation

\begin{tabular}{|c|c|c|c|c|c|}
\hline \multicolumn{2}{|l|}{ PBV } & \multicolumn{2}{|l|}{ PER } & \multicolumn{2}{|l|}{ DIVY } \\
\hline Mean & 0,697435897 & Mean & 24,09417722 & Mean & 8,047021277 \\
\hline Standard Error & 0,08465822 & Standard Error & 9,246958969 & Standard Error & 1,667354336 \\
\hline Median & 0,63 & Median & 8,5 & Median & 5,21 \\
\hline Mode & 0,44 & Mode & $\# \mathrm{~N} / \mathrm{A}$ & Mode & 5,21 \\
\hline Standard Deviation & 0,747681153 & Standard Deviation & 82,18876908 & Standard Deviation & 11,43080543 \\
\hline Sample Variance & 0,559027106 & Sample Variance & 6754,993763 & Sample Variance & 130,6633127 \\
\hline Kurtosis & 2,55362187 & Kurtosis & 35,68080245 & Kurtosis & 22,99689928 \\
\hline Skewness & 0,656933152 & Skewness & 5,852457341 & Skewness & 4,422115083 \\
\hline Range & 4,55 & Range & 599,42 & Range & 71,8 \\
\hline Minimum & $-1,47$ & Minimum & $-16,82$ & Minimum & 0,93 \\
\hline Maximum & 3,08 & Maximum & 582,6 & Maximum & 72,73 \\
\hline Sum & 54,4 & Sum & 1903,44 & Sum & 378,21 \\
\hline Count & 78 & Count & 79 & Count & 47 \\
\hline
\end{tabular}
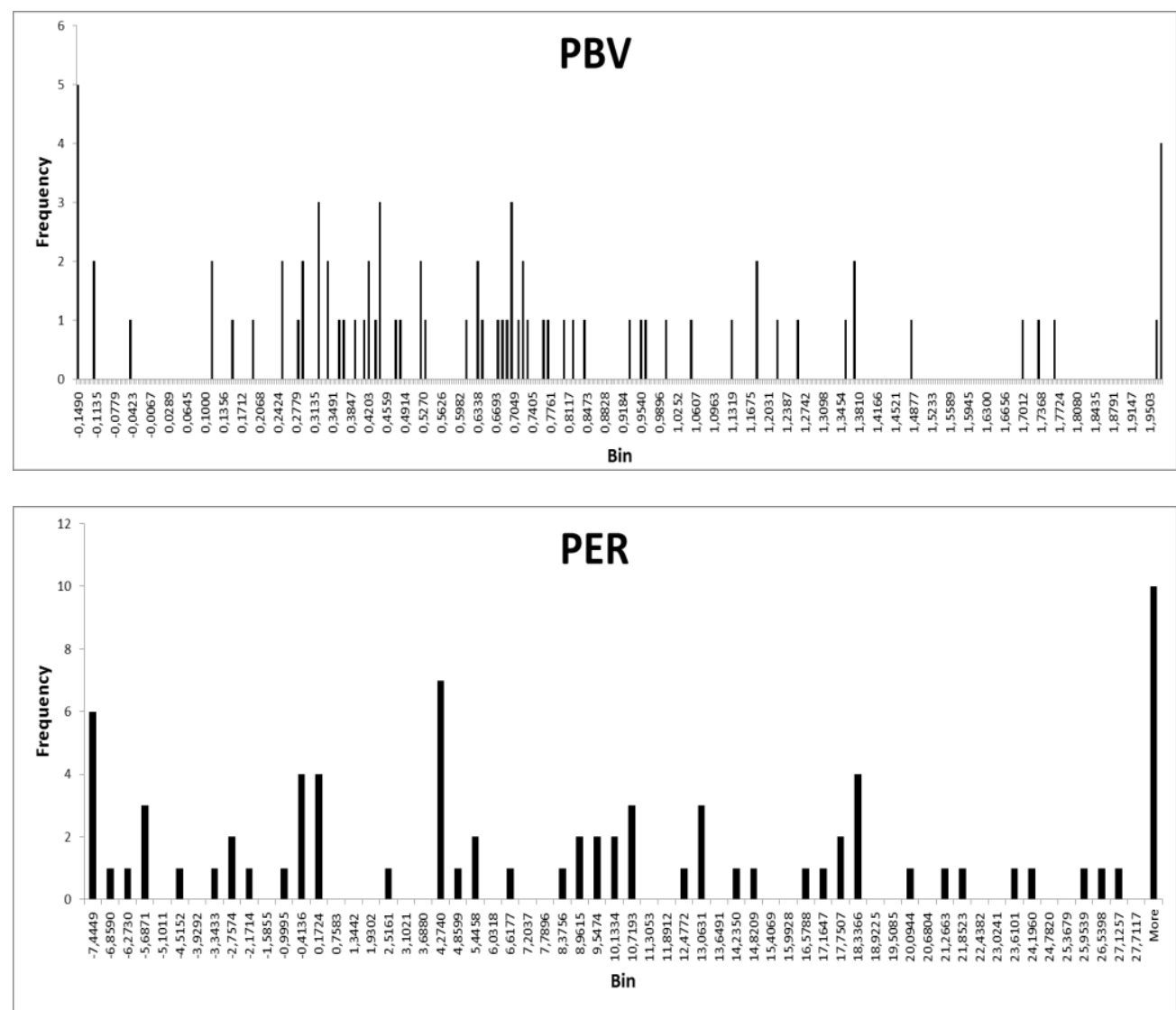

DE GRUYTER OPEN
Studia Universitatis "Vasile Goldis" Arad. Economics Series Vol 26 Issue 4/2016 ISSN: 1584-2339; (online) ISSN: 2285 - 3065 


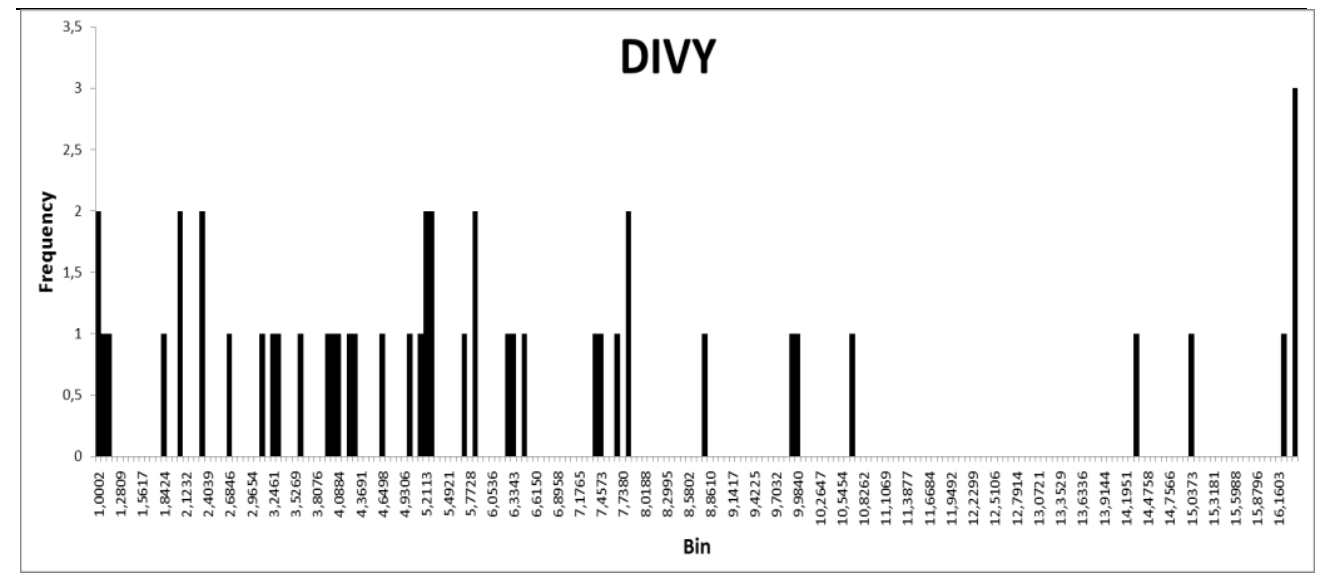

Figure 3. Statistic analyze of BVB indicators

Data source: http://www.bvb.ro/FinancialInstruments/SelectedData/Indicators

Data statistical analyses reveal that theirs distribution does not allow even a minimum degree of confidence (trust) in resulted values. Distribution is not normal, Gaussian, not being possible to use the average, respectively mean square deviation, for establishing a central value, respectively trust interval results:

- Data graphical representations enroll best in what is called discrete rectangular distribution (Balakrishnan, 2003), each of graphical values having equal probability of occurrence;

- Therefore, data are unusable for correctly estimating the value of an issuer, the assessor could choose any value from the interval, all being equiprobable. Data large dispersion and exaggerate spread between extreme values (heavy tail) involve the fact that deviations from average are unacceptably high;

- Into the interval of two dispersions around average $(\mu \pm \sigma)$ there should be 96\% contents of results, if distribution was normal (Bowerman, 2014). In PER case, in interval $(0,613 ; 0,782)$ are contained just 15 from 78 total values (19\% from data), which means it is very probable that PER value of an issuer to be far away from the average;

-Weighing with market capitalization (for establishing reference value of indicator for entire market) is especially not recommended, because an issuer with big capitalization and an indicator situated at interval border will attract removal from the average result. 
Turcas F., Dumiter F., Brezeanu P., Jimon S. (2016)

Theoretical and practical issues in business valuation

Considerations are strengthened by the evolution graphic of Facebook (FB), one of the biggest IPOs (before Alibaba listing). Listed at 38 \$/share (reaching even $45 \$$ in first moments of trading), FB share decreased relatively fast to a historical minimum (17,55 \$), giving the feeling that the initial valuation was too optimistic. But in less than a year, loss has been recuperated, valuation seemed to be reasonable. Furthermore, the share increased to values well above the initial ones (maximum at 108,80 \$), leading to the conclusion that the initial valuation was in fact, pessimistic.

Same conclusions about valuation volatility for stock exchange market can be drawn in the context of analyzing the stock market indicators values and their variations over time. This involves the fact that market valuation has a short-term relevance, less on the long-term. Conclusion encourages more investment consulting than valuation: investment recommendation is more important, at extensive time horizon, than moment value of titles.

In Figure 4 major fluctuations of market quotations for American market index Dow Jones can be noted. It can be concluded that evaluations are available only at valuation date (as standards actually claim), but they lose very quickly the effects, because market equilibrium is a dynamic one.

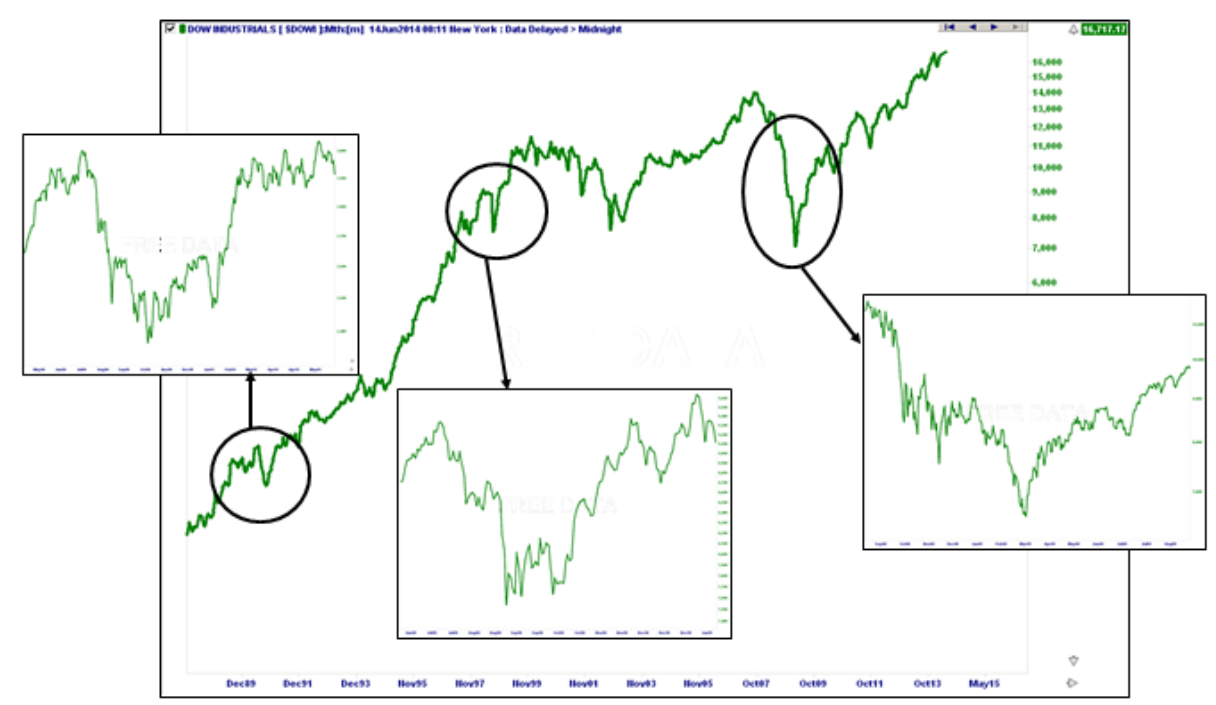

Figure 4. Random fluctuations of stock market price

Graphic source: Informatics application IncredibleCharts Pro, DJIA graphic

DE GRUYTER OPEN
Studia Universitatis "Vasile Goldis" Arad. Economics Series Vol 26 Issue 4/2016 ISSN: 1584-2339; (online) ISSN: 2285 - 3065 
Turcas F., Dumiter F., Brezeanu P., Jimon S. (2016)

Theoretical and practical issues in business valuation

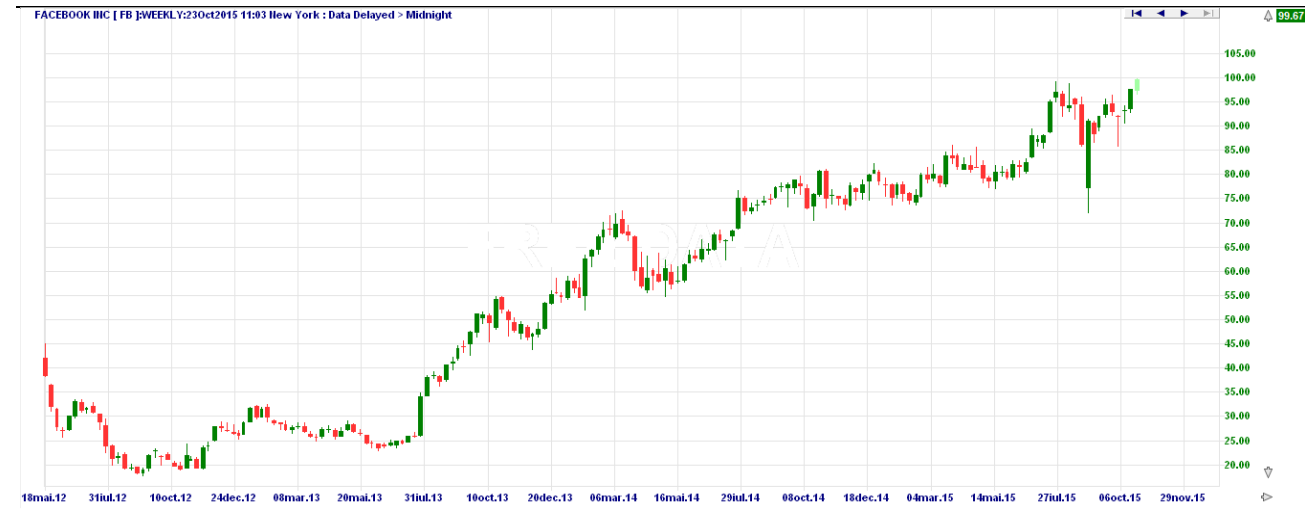

Figure 5. Facebook graphic (FB)

Source: Informatics application IncredibleCharts Pro, FB graphic

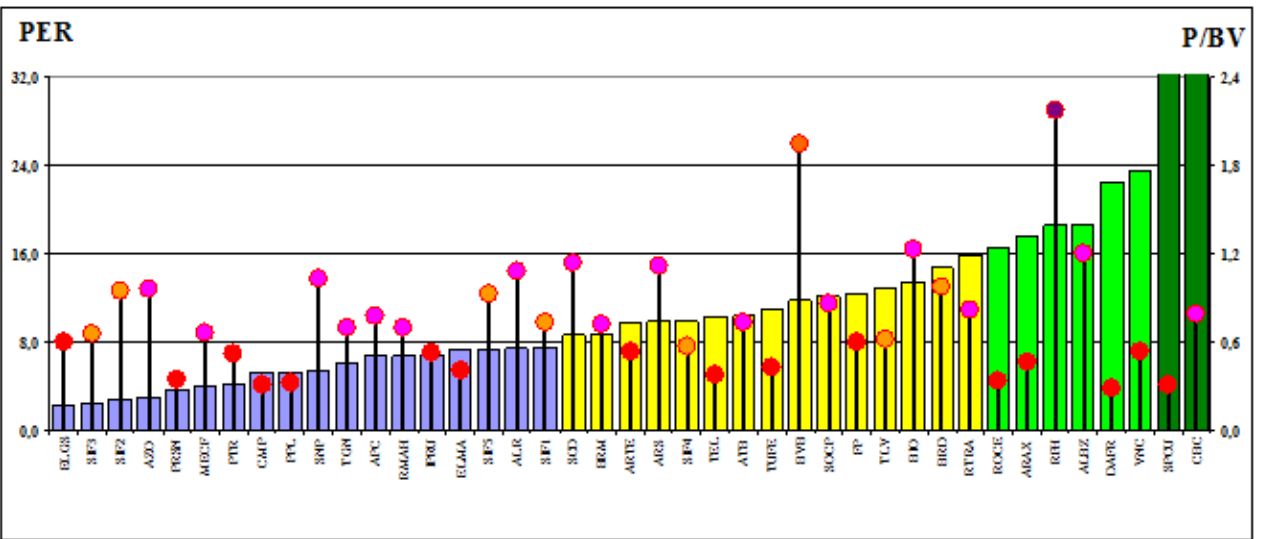

Figure 6. Stock market indicators diversity on Romanian market

Source: Data processed by authors based on BVB announcements

Statement „market is always right” addresses more to speculators than assessors, especially in the context of financial and stock crisis triggered in the summer of 2007. Than it was demonstrated that market is an economic environment unable to self-regulate if big perturbations emerge, being necessary state intervention.

Market values fluctuations encourage us to approach the valuation problem under the investment recommendations aspect: entry and exit points in market (stop loss/take profit), respectively under the aspect of expected profitability and afferent risk (buy/hold/sell). 
Table 4. Variation of stock market indicators over time

\begin{tabular}{|c|r|r|r|}
\hline Date & \multicolumn{1}{|c|}{ PER } & \multicolumn{1}{c|}{ P/B V } & \multicolumn{1}{c|}{ DY } \\
\hline 20.11 .2006 & 17,96 & 2,75 & 1,67 \\
\hline 31.07 .2007 & 22,38 & 3,30 & 1,99 \\
\hline 24.02 .2009 & 2,56 & 0,49 & 13,41 \\
\hline 09.04 .2010 & 19,71 & 1,42 & 2,06 \\
\hline 09.11 .2011 & 8,50 & 0,86 & 5,14 \\
\hline 26.09 .2012 & 6,91 & 0,88 & 7,27 \\
\hline 01.03 .2013 & 8,17 & 1,01 & 6,44 \\
\hline 06.01 .2014 & 9,53 & 0,98 & 5,81 \\
\hline 05.01 .2015 & 7,01 & 0,91 & 8,20 \\
\hline 30.11 .2015 & 11,70 & 0,88 & 5,32 \\
\hline May 2016 & 5,72 & 0,74 & 7,70 \\
\hline
\end{tabular}

Data source: Bucharest Stock Exchange (BVB)

\section{Income approach}

It is the most modern method, being treated in many theoretical and practical materials. After market valuation, it is the most often used approach, being destined especially to investors.

\section{Theoretical considerations}

Discounted cash flow method (DCF, updated cash flow) is frequently used for enterprises, rights over real estates and intangible assets valuation. Enterprises value through discounted cash flow is based on formula:

$$
\mathrm{Vi}=\sum_{\mathrm{p}=1}^{\mathrm{n}} \frac{\mathrm{CFNI}_{\mathrm{i}}}{(1+\mathrm{k})^{\mathrm{p}}}+\frac{\mathrm{Vt}_{\mathrm{n}}}{(1+\mathrm{k})^{\mathrm{n}}}
$$

In which $\mathrm{Vi}=$ enterprise value (invested capital), $\mathrm{n}=$ duration in years of explicit forecast period, $\mathrm{CFNI}_{\mathrm{i}}=$ net cash flow at enterprise disposition in i year, $\mathrm{Vt}=$ terminal value at the end of the year $\mathrm{n}, \mathrm{k}=$ actualization rate.

Net cash flow for enterprise (Free Cash Flow to the Firm) is estimated by anticipating the method and usually it is calculated by indirect method: normalized net profit plus amortization minus capital expenses minus net floating capital increase plus long time loans increase minus dividends for preferred shares. Cash

DE GRUYTER OPEN
Studia Universitatis "Vasile Goldis" Arad. Economics Series Vol 26 Issue 4/2016 ISSN: 1584-2339; (online) ISSN: 2285 - 3065 
flow for shareholders is calculated by deduction interests and loans refunds from cash flow to the firm.

Discount rate is calculated by weighted average (WACC):

$$
\mathrm{k}=\mathrm{k}_{\mathrm{c}} \cdot \frac{\mathrm{CP}}{\mathrm{Vi}}+\mathrm{k}_{\mathrm{p}} \cdot \frac{\mathrm{CPr}}{\mathrm{Vi}}+\mathrm{k}_{\mathrm{d}} \cdot(1-\mathrm{S}) \cdot \frac{\mathrm{CT}}{\mathrm{Vi}}
$$

In which $\mathrm{k}=$ weighed average cost of capital, $\mathrm{k}_{\mathrm{c}}=$ own capital cost, $\mathrm{CP}=$ own capital market value (assimilated to market capitalization), $\mathrm{k}_{\mathrm{p}}=$ preferred shares cost, $\mathrm{CP}_{\mathrm{r}}=$ preferred shares market value, $\mathrm{k}_{\mathrm{d}}=$ loan cost before tax, $\mathrm{CT}=$ total loans, $\mathrm{S}=$ profit tax rate, $\mathrm{Vi}=$ market enterprise value (invested capital).

Own capital cost is determined:

- From market comparisons;

- It can be built in stages: risk-free base rate plus specific risk rates:

○ CAMP model (Capital Asset Pricing Model):

$$
\mathrm{k}_{\mathrm{c}}=\mathrm{Rf}+\beta \cdot(\mathrm{Rm}-\mathrm{Rf})+\operatorname{Pr} \mathrm{c}+\operatorname{Pr} \mathrm{n}
$$

Where $\mathrm{Rf}$ is basic nominal risk-free rate, $\beta=$ investment systematic risk, $\mathrm{Rm}=$ return average rate on stock market, $(\mathrm{Rm}-\mathrm{Rf})=$ risk premium on stock market, $\operatorname{Prc}=$ additional risk premium for small listed enterprises, Prn $=$ unsystematic risk premium for unlisted enterprises.

$$
\begin{aligned}
& \circ \quad \text { APM model (Arbitrage Pricing Model): } \\
& \mathrm{k}_{\mathrm{c}}=\mathrm{Rf}+\sum \mathrm{P}_{\mathrm{i}} \cdot \beta_{\mathrm{i}}
\end{aligned}
$$

With $P_{i}=$ risk premium associated to economic factors, $\beta_{i}=$ issuers sensitivity at risk factors;

- Can be estimated by Gordon dividend growth model:

$$
\mathrm{k}=\frac{\mathrm{D} \cdot(1+\mathrm{g})}{\mathrm{Cex}}+\mathrm{g}
$$

Where $\mathrm{D}=$ current dividend per share, $\mathrm{g}$ = dividends annual constant growth forecasted rate, $\mathrm{Cex}=$ ex-dividend market course of share.

Terminal value Vt can be determined through patrimonial methods (only in case of business liquidation) by comparison or income based (profit capitalization or net cash flow).

Profit capitalization method is a simplified method of DCF, applicable when enterprise is in cruise stage, and representative profit can be thoroughly justified:

$$
\mathrm{Vi}=\frac{\mathrm{P} \cdot(1+\mathrm{g})}{\mathrm{c}=\mathrm{k}-\mathrm{g}}
$$

In which $\mathrm{P}=$ profit representative value in base year, $\mathrm{g}=$ annual perpetual constant growth forecasted rate, $\mathrm{c}=$ capitalization rate. 


\section{Identified problems}

The main problems in applying approach consist of:

- Difficulty in practical substantiation of cash flow at shareholders service, respectively invested capital;

- The establishment of actualization rate, respectively capitalization rate. Wide variations are found by diverse authors, leading to results practically located in a beach of too large values;

- Sensitivity of evaluated value in relation with capitalization rate;

- Unjustified rise of disposable in numerical simulations;

- The fact that two companies with radically different sizes can obtain the same result (respectively, future similar results can be forecasted), which lead to equal theoretical values of enterprises.

Applying multipliers to domestic stock market with the values available at 11 . 11.2015 on BVB site, is shown in Table 5. Issuers have been selected, that have near profits and which should have the same market capitalization, if PER indicator would be decisive for all market participants. The discrepancy between market values of titles is being observed, fact that imposes a thorough analysis of indicators applicability in valuation of listed enterprises.

Table 5. Indicators of some BVB listed enterprises

\begin{tabular}{lrrrr}
\hline \multicolumn{1}{c}{ Symbol } & Capitalization & \multicolumn{1}{c}{ Own capitals } & \multicolumn{1}{c}{ PER } & \multicolumn{1}{c}{ Profit } \\
\hline ALBZ & 202.339 .749 & 98.487 .184 & 24,09 & 8.399 .325 \\
CMF & 70.238 .820 & 78.969 .120 & 8,57 & 8.195 .895 \\
PTR & 78.171 .643 & 161.318 .656 & 8,83 & 8.852 .961 \\
RPH & 178.359 .776 & 122.465 .664 & 21,76 & 8.196 .681 \\
\hline
\end{tabular}

Source: http://www.bvb.ro/FinancialInstruments/SelectedData/Indicators

From assessors, but especially from investors, the question is: should they invest in a small enterprise, but with high profitability (PER), or, against, in a big one, even if relative profitability is lower? It is assumed that a smaller enterprise is more flexible and has a more efficient management, and the bigger one is more solid, having resources to pass over the eventual crises.

In fact, DCF approach considers that company value is given by cash surplus released and which is not necessary to exploitation (which can be distributed to shareholders). This approach does not count under any circumstances (except some calculation alternatives of residual value), of company assets value, which makes a 
small and very profitable company to have same value as a big one, but which produces the same global result. Modern alternatives of approach consider capitalization on extra profit, which are summed with company assets value.

\section{Reconciliation of values}

Regarding the three approaches, assessors have to select that value in which they have the highest confidence, both in terms of available data and of the perspective of market participants.

\section{Practical problems}

The problem which arises is whether the approaches are irreconcilable.

When there are no express legal stipulations, the assessor is prevented from making the average of values resulted from different valuations, because they are based on different reasons, their average has no economic sense.

There is no logical explanation for introducing new legislative regulations to impose on average values, than the fact that most negotiations are finalized ,at middle" between seller claims and buyer availabilities.

There have been attempts to make connections between enterprises fundamental values and their trading price on the market. In the correspondence carried out with Dr. Bart A. DiLiddo, this proposed a newer version of empirical formula, posted on the vectorvest.com site, which, according to author, folds good enough on the S\&P500 index.

$$
V=100 \times \frac{E}{I Y+Y P} \times \sqrt{\frac{R+G / 2}{Y I-Y P-F}}
$$

With, V = Stock Value, E = Earning/Share (\$), IY = Interest Rate (\%), YP = Yield Premium, $\mathrm{R}=\%$ Return on Total Capital, $\mathrm{G}=$ Earning Growth (\%/year), $\mathrm{F}=$ Inflation Rate (\%/year).

On domestic market, older and newer own studies confirm major discrepancies between issuers' fundamental values and their stock market behavior. These differences can't be attributed only to the stock market fluctuations, as elements completely outside the issuers (exogenous factors).

In Figure 7 we have presented graphics resulted from own calculations, according to the relationship between the stock market course, net profit and own capitals of issuer SIF1 on domestic stock market. The results confirm random variations of traded price, variations which should be able to be statistically quantified. 
Turcas F., Dumiter F., Brezeanu P., Jimon S. (2016)

Theoretical and practical issues in business valuation

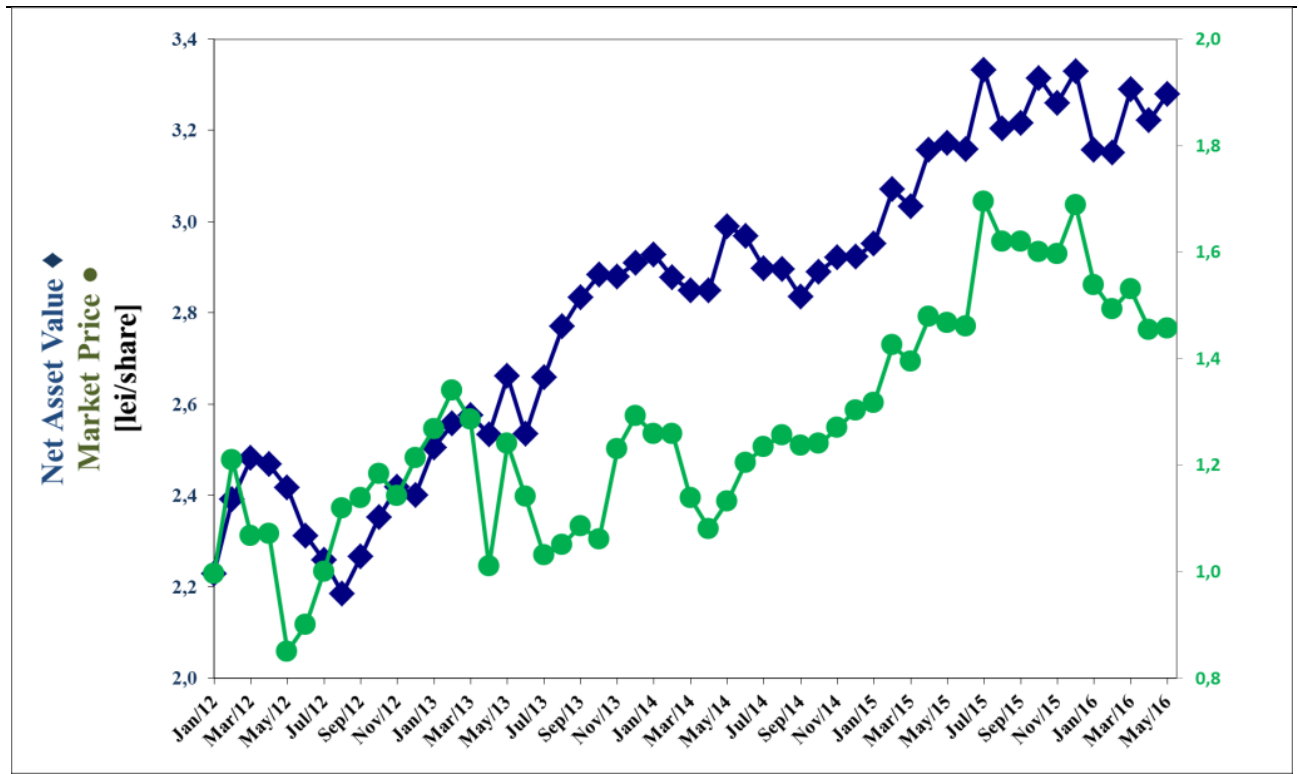

Figure 7. Discrepancies between issuer values, results from diverse approaches Source: Data processed by the authors based on available information on site www.bvb.ro

Another possible cause of differences between values obtained by diverse approaches is constituted by premiums and discounts. Among the most important we mention: the lack of liquidity or trading, the lack of control, reduced exposure to market (liquidation value). Their determinations remain a spiny problem, worth taking into account (including level of academic studies). On American market, for example, the judicial courts accept discounts placed between $20 \div 75$ percents.

Table 6. Reconciling values resulted from valuation

\begin{tabular}{|c|c|c|c|}
\hline Valuated values & Source/Value & Total [lei] & Unitar [lei/actiune] \\
\hline Nominal Value & & 12.240 .036 & 12,98 \\
\hline Approach through multiplier P/BV & 0,93 & 20.663 .367 & 21,91 \\
\hline Accounting Value & Balance & 22.218 .674 & 23,56 \\
\hline Cost approach (ajusted net asset) & $\mathbf{A N C}$ & 25.801 .204 & 27,36 \\
\hline Stock market capitalization - Actual cotation & BVB & 5.657 .952 & 6,00 \\
\hline Trade average & BVB & 7.011.742 & 7,44 \\
\hline Approach through comparison with the market PER & 7,16 & 11.990 .315 & 12,72 \\
\hline Value resulted through DCF application & & $\mathbf{1 1 . 8 2 5 . 1 2 0}$ & $\mathbf{1 2 , 5 4}$ \\
\hline
\end{tabular}

Source: Example from an issuer case studied by authors

DE GRUYTER OPEN
Studia Universitatis "Vasile Goldis" Arad. Economics Series Vol 26 Issue 4/2016 ISSN: 1584-2339; (online) ISSN: $2285-3065$ 
In Table 6 we have synthesized the results obtained by valuation of a Romanian enterprise. Leaving aside the pressures exerted in practice (from majority shareholders to minority ones, loans institutions, fiscal authorities, even press, etc.), from a theoretical point of view it is difficult to establish which values better reflect the enterprise reality.

\section{Practical solutions}

In assessors' professional environment, the custom to affect differences is being set as follows:

- The difference between yield and patrimonial value is attributed to an undifferentiated intangible active (incorporeal), generically named goodwill (badwill in negative case);

- The difference between market and fundamental value is justified by market fluctuation, without any other rational explanation;

- The difference between traded values on market and integral value of enterprise is justified through discounts (premiums, if there is the case), very difficult to substantiate not only theoretically, but also practically.

\section{Conclusions}

In this paper the diverse limitations of actual approaches in valuation were highlighted, as well as some interpretations, theoretical and practical ones, more or less controversial.

After the study, we conclude that, in fact, all approaches are similar and it is based on applying some multipliers at comparable values, resulted from known trades. It is the case of net replacement costs (where multipliers are represented by depreciation), cash flow value (multipliers being the reverse of capitalization rate), respectively market value (through applying stock market indexes).

In our opinion there is no absolute value (intrinsic), and all valuations are based on comparison with other assets value, more or less similar.

The conclusion is natural, if we think that there is not an absolute reference for currency (not even gold); therefore there can't be an absolute reference neither for assets measured using currency.

In the following we enumerate some of the study directions which can be deepened, both from a practical point of view, but especially from a theoretical (academic) point of view:

- Value interpretation of some accounting position (see differences between national, European and American standards);

- Identification and calculating the value of some untouchables; 
- Contributions to enactment (normalization) of calculating VUAN for investment funds, in case of assets untraded on regulated markets;

- Theoretical justification of differences between $\beta$ coefficient values determined for diverse sectors, in CAMP approach (derived from Modern Theory of Portfolio);

- Substantiating investment recommendations of type buy/hold/sell, with integration forecasting time interval and market risk;

- Establishing limits in which market is self - regulating and the point where state intervention is necessary;

- Scientific substantiating of discounts;

- Theoretical bases of differences allocations between values resulted from different approaches.

Valuation field seems to have reached the maturity and, apparently, not much can be said.

Large numbers of specialty papers appeared lately, as well as discrepancies between the approaches and/or assessors in applying classical methods that encourage us to persevere in the attempt to bring a contribution to the field.

The question is: if all shares are correctly evaluated, will they be traded on the market? Who would buy those shares which do not rise (because were correctly valuated at buying)? Who would sell shares, because it is pointless to buy other shares, just accurately valuated? Because the market is active, it means that many buyers have the impression that shares are undervalued, respectively many sellers consider that they are already overvalued. Together with the stock market evolution study, titles valuation remains an exciting study area, both theoretically and practically.

\section{References}

1. Abrams, Jay B. Quantitative Business Valuation. A Mathematical Approach for Today's Professionals, Second Edition. Wiley \& Sons Ltd., 2010. ISBN 978-0-47039016-0 (cloth).

2. Balakrishnan, N.; Nevorov, V.B. A primer on statistical distributions, John Wiley \& Sons, Inc., 2003

3. Baker, Kent H.; Kiymaz, Halil. The Art of Capital Restructuring. Creating Shareholders Value through Mergers and Acquisitions. John Wiley \& Sons, Inc., 2011. ISBN 978-1-11803035-6 (ebk.)

4. Bowerman, Bruce L.; O’Connell, Richard T.; Murphree, Emily S. Business Statistics in Practice - Seventh edition. McGraw-Hill/Irwin, 2014

5. Calandro, Joseph Jr. Applied Value Investing. McGrave Hill, 2009. ISBN 978-0-07162819-8.

Studia Universitatis "Vasile Goldis" Arad. Economics Series Vol 26 Issue 4/2016 ISSN: 1584-2339; (online) ISSN: $2285-3065$ 
6. Choudhry, Moorad; Joannas, Didier; Landuyt, Gino; Pereira, Richard; Pienaar, Rod. Capital Market Instruments. Analysis and Valuation, 3rd Edition. Palgrave Macmillan, 2010. ISBN 978-0-230-57603-2 paperback.

7. DePamphilis, Donald M. (2011) Mergers and Acquisitions Basics. Negociation and Deal Structuring. Academic Press, Elsevier. ISBN 978-0-12-374949-9

8. DePamphilis, Donald M. (2012) Mergers, Acquisitions and Other Restructuring Activities. Academic Press, Elsevier. ISBN 978-0-12-385485-8

9. Dodel, Kerstin. Private Firm Valuation and M\&A. Wiley \& Sons Ltd., 2014. Epdf 9781119960485.

10. Fabozzi, Frank J. et.a. (2014) The Basics of Financial Econometrics. Tools, Concepts, and Asset Management Applications. Wiley. ISBN 978-1-118-72743-0 (ePDF)

11. Fabozzi, Frank J.; Markowitz, Harry M. Equity Valuation and Portfolio Management. Wiley \& Sons Ltd., 2011. 978-1-118-15654-4 (ebk).

12. Galpin, Timothy J.; Herndon, Mark (2014) The Complete Guide to Mergers \& Acquisitions. Process Tools to Support M\&A Integration at Every Level. Jossey-Bass, a Wiley Brand. ISBN 978-1-118-82702-4 (epub).

13. Larrabee, David T.; Voss, Jason A. Valuation Techniques. Wiley \& Sons Ltd., 2013. ISBN 978-1-118-45017-8 (ebk).

14. Massari, Mario; Gianfrate, Gianfranco; Zanetti, Laura. The Valuation of Financial Companies. John Wiley \& Sons Ltd., 2014. ISBN 9781118821367 (ebk).

15. Melka, Lionel; Shabi, Amit (2013) Merger Arbitrage. A Fundamental Approach to Event-Driven Investing. Wiley Finance ISBN 978-1-118-44006-3 (ebk.)

16. Miller, Warren D. Value Maps. Valuation Tools That Unlock Business Wealth. Wiley \& Sons Ltd., 2010. ISBN 978-0-470-43756-8 (cloth).

17. Palepu, Krishna G.; Healy, Paul M.; Peek, Erik. Business Analysis and Valuation: IFRS edition, Third Edition. Cengage Learning EMEA, 2013. ISBN: 978-1-40805642-4.

18. Perna, Cira; Sibillo, Marilena (2014) Mathematical and Statistical Methods for Actuarial Sciences and Finance. Springer. ISBN 978-3-319-05013-3

19. Petitt, Barbara S.; Ferris, Kenneth R. (2013) Valuation for Mergers and Acquisitions. Person Educations, Inc. ISBN-10: 0-13-337267-7

20. Pinto, Jerald E.; Henry, Elaine; Robinson, Thomas R.; Stowe, John D. Equity Asset Valuation. Second Edition. Wiley \& Sons Ltd., 2010. ISBN 978-0-470-57143-9 (hardback).

21. Pratt, Shannon P. Business Valuation Discounts and Premiums. John Wiley\&Sons, Inc., 2009. ISBN 978-0-470-37148-0 (cloth).

22. Ratner, Ian; Stein, Grant; Weitnauer, John C. Business Valuation and Bankruptcy. John Wiley\&Sons, Inc., 2009. ISBN 978-0-470-46238-6.

23. Shapiro, Eric; Mackmin, David; Sams, Gary. Modern Methods of Valuation. 11th edition. Routledge, 2013. ISBN: 978-0-08-097117-9 (ebk).

24. Schmidlin, Nicolas. The Art of Company Valuation and Financial Statement Analysis. John Wiley \& Sons Ltd., 2014. ISBN 9781118843048 (ebk). 
Turcas F., Dumiter F., Brezeanu P., Jimon S. (2016)

Theoretical and practical issues in business valuation

25. Thomas, Rawley; Gup, Benton E. The Valuation Handbook. Valuation Techniques from Today's Top Practitioners. John Wiley\&Sons, Inc., 2010. ISBN 978-0-47038579-1 (hardback).

26. Zhang, Guochang. Accounting Information and Equity Valuation. Springer, 2014. ISBN 978-1-4614-8160-7 (eBook).

27. Canadian Uniform Standards Of Professional Appraisal Practice. Appraisal Institute of Canada, 2010.

28. OECD Transfer Pricing Guidelines for Multinational Enterprises and Tax Administrations, 2010.

29. http://asfromania.ro/legislatie/legislatie-sectoriala/legislatie-capital/legislatie-primaracnvm/2633-legea-297-2004-piata-de-capital-legislatie

30. http://asfromania.ro/legislatie/legislatie-sectoriala/legislatie-capital/legislatiesecundara-cnvm/regulamente-cnvm/353-2006-regulamente-capital-legislatie/2432regulamentul-nr-01-privind-emitentii-si-operatiunile-cu-valori-mobiliare.

31. http://effisols.com/download/index.htm

32. http://epp.eurostat.ec.europa.eu/cache/

33. http://en.wienerborse.at/

34. http://eur-lex.europa.eu/legalcontent/RO/TXT/?qid=1432275880954\&uri=CELEX:02008R1126-20150112

35. http://legislatie.just.ro/Public/DetaliiDocument/798

36. http://nou.anevar.ro/sites/default/files/page-files/og_24_2011_versiune_consolidata.pdf

37. https://static.anaf.ro/static/10/Anaf//legislatie/OMFP_1802_2014.pdf

38. http://stockcharts.com/freecharts/

39. http://stooq.com/

40. http://www.bvb.ro/

41. http://www.incrediblecharts.com/

42. http://www.ivsc.org/

43. http://www.rics.org/ro/knowledge/professional-guidance/redbook/red-book-2014-infull/

44. http://www.tegova.org/en/p4912f1dc0472d

Studia Universitatis "Vasile Goldis" Arad. Economics Series Vol 26 Issue 4/2016 ISSN: 1584-2339; (online) ISSN: $2285-3065$

Web: publicatii.uvvg.ro/index.php/studiaeconomia.Pages $1-23$ 